\title{
Smoking and alcohol consumption in Trent, UK: an analysis of item non-response
}

\author{
Regina Dengler
}

In postal studies, bias may be introduced through respondents failing to complete all the questions. This is referred to here as, "item non-response", 1 and is in addition to any bias caused by total non-response, ${ }^{1}$ such as the under representation of smokers. ${ }^{2}$ A better understanding of item non-response should therefore help in the interpretation of data generated by postal surveys. It was decided to study item non-responders in respect of two key concerns in the Trent health lifestyle survey carried out in $1994 .^{3}$ These key concerns were smoking status, drinking status and level of alcohol consumption. ${ }^{4}$

\section{Method}

Eighty people $(0.7 \%)$ who omitted the question on smoking status and $657(5.7 \%)$ who omitted to mark their level of alcohol consumption were sent the relevant page from the original questionnaire and a covering letter on 23 June 1994, about four months after the original study. One reminder, a covering letter, and a second page of questions were sent on 14 July 1994 to those who still had not replied.

\section{Results}

RESPONSE

The response rate for the original survey was $66 \%{ }^{3}$ For the item non-response study the response rate was $78 \%$ (60/77, 3 exclusions) for those who omitted information on smoking and $79 \%$ (512/650, 7 exclusions) for those who did not indicate their alcohol consumption in the original survey.

\section{SMOKING}

There was no significant difference in smoking status between those who responded to the item non-response study and those who the Survey, Department of Public Health Medicine, University Hospital, Queen's Medical Centre, Nottingham NG7 2UH R Dengler.

Correspondence to: Ms R Dengler. Accepted for publication June 1996

f Epidemiol Commun Health 1996;50:687
Trent Health Lifestyle

with $31.7 \%(19 / 60)$ and $27 \%(3064 / 11367)$ smokers in both studies respectively. Nor was there any significant difference between the two studies in the daily cigarette consumption of smokers.

\section{ALCOHOL}

Following a question on drinking status, those who drank alcohol were asked whether they drank in the week before the survey, and if so, how much of several alcoholic drinks they consumed on the various days of that week. This was then used to calculate whether someone drank more than the recommended number of units per week. ${ }^{5}$ Table 1 compares the responses from the original survey with those from the item non-response study. It shows that significantly fewer respondents drank "more than the recommended units" in the item non-response study than in the original survey. On the other hand, the percentage of item non-responders who had drunk "less than the recommended units" was significantly higher than in the original study.

\section{Conclusion}

This study does not support the hypothesis that bias is introduced in the estimate of smoking prevalence through item non-response in a lifestyle survey. This study also suggests that the original survey may have slightly over estimated alcohol consumption above the recommended level. The over estimation would, however, be less than $0.2 \%$.

1 Moser CA, Kalton G. Survey methods in social investigation. 2nd ed. Aldershot: Dartmouth Publishing Company Limited, 1971.

2 Smith C, Nutbeam D. Assessing non-response bias: a case study from the 1985 Welsh Heart Survey. HER 1990;5: study from.

3 Roberts H, Dengler R, Zamorski A. Trent health lifestyle survey: technical report to Trent Regional Health Authority, 1993/94. technical report to Trent Regional Health Authority

4 Department of Health. The health of the nation: a strategy for health in England. London: HMSO, 1993. completed original survey question on smoking status $\left(\chi^{2}=0.67\right.$ with 1 degree of freedom), 5 Royal College of Psychiatrists. Alcohol: our favourite drug. London: Tavistock Publications, 1986.

Table 1 Level of alcohol consumption in the original study compared with the item non-response study

\begin{tabular}{lcc}
\hline Level of alcohol consumption & $\begin{array}{l}1994 \text { lifestyle study } \\
\text { No (\%) }\end{array}$ & $\begin{array}{l}\text { Item non-response study } \\
\text { No (\%) }\end{array}$ \\
\hline $\begin{array}{l}\text { Teetotal } \\
\text { Fewer than the recommended number of }\end{array}$ & $1569(14.6)$ & $40(7.8)$ \\
units & $7428(70.0)$ & $414(80.9)$ \\
$\begin{array}{l}\text { More that the recommended number of units } \\
\text { All }\end{array}$ & $1773(16.4)$ & $58(11.3)$ \\
$\chi^{2}=32.45$ with 2 df, p,0<0.001 & $10770(100)$ & $512(100)$ \\
\hline
\end{tabular}

